AL IBTIDA: JURNAL PENDIDIKAN GURU MI (2018) VOL 5 (2) : 261-274

DOI: http://dx.doi.org/ 10.24235/al.ibtida.snj.v5i2.3374

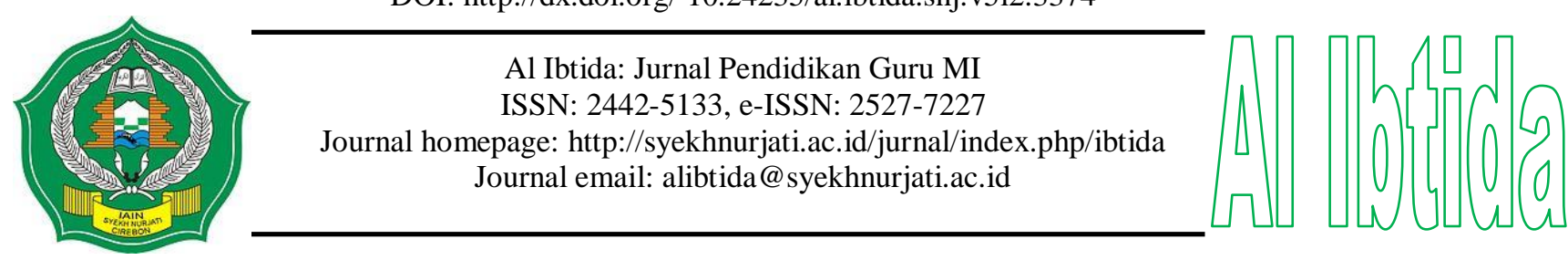

\title{
Pengaruh Model Pembelajaran Inkuiri Terhadap Kemampuan Pemecahan Masalah Matematika Siswa Kelas IV Madrasah Ibtidaiyah
}

\author{
Ahmad Arifuddin* \\ *Program Studi Pendidikan Guru Madrasah Ibtidaiyah, Fakultas Ilmu Tarbiyah dan Keguruan, \\ IAIN Syekh Nurjati Cirebon \\ Email: arifuddin@syekhnurjati.ac.id \\ Dwi Anita Alfiani** \\ **Program Studi Pendidikan Guru Madrasah Ibtidaiyah, Fakultas Ilmu Tarbiyah dan Keguruan, \\ IAIN Syekh Nurjati Cirebon \\ Email: deamers77@gmail.com \\ Sri Hidayati*** \\ ***Program Studi Pendidikan Guru Madrasah Ibtidaiyah, Fakultas Ilmu Tarbiyah dan Keguruan, \\ IAIN Syekh Nurjati Cirebon \\ Email: srihidayati2195@gmail.com
}

Received 18 October 2018; Received in revised form: 27 October 2018; Accepted 29 October 2018 Publish Online: 31 October 2018

\begin{abstract}
Abstrak
Penelitian ini dilatar belakangi oleh rendahnya kemampuan siswa dalam memecahkan masalah matematika khususnya pada materi pecahan. Hal ini dapat dilihat dari hasil ulangan harian materi pecahan yang masih rendah yakni di bawah Kriteria Ketuntasan Minimal (KKM). Tujuan penelitian ini adalah untuk mengetahui ada tidaknya pengaruh model pembelajaran inkuiri terhadap kemampuan pemecahan masalah matematika siswa pada materi pecahan di Kelas IV MI Hidayatus Shibyan. Penelitian ini merupakan penelitian kuantitatif dengan metode eksperimen. Teknik pengumpulan data yang digunakan adalah teknik observasi, tes, dan dokumentasi. Sementara itu data hasil penelitian dianalis menggunakan uji analisis data observasi, uji $\mathrm{N}$-gain, dan uji regresi. Hasil penelitian ini menunjukkan bahwa berdasarkan hasil observasi aktivitas guru pada proses pembelajaran sebesar $83 \%$ dengan kategori baik dan hasil obsevasi aktivitas siswa sebesar 60\% dengan kategori cukup. Sementara itu kemampuan pemecahan masalah matematika siswa mengalami peningkatan sebesar 0,78 dengan kategori tinggi. Dan berdasarkan hasil uji regresi menunjukkan bahwa nilai signifikansinya sebesar 0,001 lebih kecil dari 0,05 dan $\mathrm{t}$ hitung sebesar 4.168 lebih besar dari $\mathrm{t}$ tabel yakni 1.734, maka Ho ditolak. Ini berarti bahwa terdapat pengaruh yang signifikan antara penggunaan model pembelajaran inkuiri terhadap kemampuan pemecahan masalah matematika siswa pada materi pecahan di kelas IV MI Hidayatus Shibyan.
\end{abstract}

Kata kunci: model pembelajaran inkuiri, pemecahan masalah, matematika 


\begin{abstract}
This research is based on the low ability of students in solving mathematical problems, especially in fractional material. This can be seen from the results of the daily review of the fractional material which is still low, which is under the Minimum Completeness Criteria (KKM). This research aims to determine whether there was an influence of the inquiry learning model on students' mathematical problem-solving ability in fraction material in Class IV MI Hidayatus Shibyan. This research is a quantitative research with an experimental method. Data collection techniques used are observation, test, and documentation techniques. Meanwhile the research data is analyzed using the analysis of observation data, $\mathrm{N}$-gain test, and regression test. The results of this research indicate that based on observations of teacher activities in the learning process by $83 \%$ with good categories and the results of student activity observation by $60 \%$ with sufficient categories. Meanwhile, students' mathematical problem solving abilities have increased by 0.78 in the high category. And based on the results of the regression test shows that the significance value is 0.001 less than 0.05 and $t$ count is 4.168 greater than table is 1.734 , then Ho is rejected. This means that there is a significant influence between the use of inquiry learning models on students' mathematical problem solving skills in fraction material in class IV MI Hidayatus Shibyan.
\end{abstract}

Keywords: inquiry learning model, problem solving, mathematics

\title{
PENDAHULUAN
}

Pendidikan merupakan usaha sadar dan terencana untuk mewujudkan suasana belajar dan proses pembelajaran untuk peserta didik secara aktif mengembangkan potensi dirinya untuk memiliki kekuatan spiritual keagamaan, pengendalian diri, kepribadian, kecerdasan, akhlak mulia, serta keterampilan yang diperlukan dirinya dan masyarakat. Menurut (Anam, 2016) Pendidikan merupakan proses pembelajaran di mana peserta didik menerima dan memahami pengetahuan sebagai bagian dari dirinya, dan kemudian mengolahnya sedemikian rupa untuk kebaikan dan kemajuan bersama agar tercapainya tujuan pendidikan.

Keberhasilan tujuan pendidikan dipengaruhi oleh sistem pembelajaran di mana komponen utamanya adalah siswa dan guru. Kedua komponen tersebut saling berinteraksi. Siswa menerima berbagai pengetahuan yang ditransformasikan guru. Siswa sebagai subjek dalam belajar biasanya terjadi dalam belajar kelompok, guru berperan sebagai fasilitator. Ini merupakan upaya dalam menciptakan belajar salah satunya dalam pembelajaran matematika.

Menurut (Arifuddin \& Arrosyid, 2017) Matematika sebagai mata pelajaran yang membentuk pola pikir seseorang berfikir terstuktur dan logis perlu dipelajari sedini mungkin. Dengan belajar matematika, siswa diharapkan dapat menghubungkan dan memahami suatu hubungan antara konsep matematika yang satu dengan dengan konsep matematika yang lain untuk memecahkan masalah dalam kehidupan sehari-hari. Akan tetapi permasalahannya adalah guru belum mampu menyampaikan materi matematika yang abstrak tersebut dengan baik, sehingga siswa merasa kesulitan dalam mempelajari materi matematika. Terlebih dalam 
pembelajaran matematika dibutuhkan kemampuan dalam memahami dan memecahkan masalah (Udin \& Hikmah, 2014).

Kemampuan pemecahan masalah adalah satu usaha mencari jalan keluar dari satu kesulitan guna mencapai satu tujuan yang tidak begitu mudah segera untuk dicapai. Dan pada dasarnya kemampuan pemecahan masalah dalam matematika adalah kemampuan siswa dalam menyelesaikan masalah matematika dengan memperhatikan proses menemukan jawaban berdasarkan langkah-langkah pemecahan masalah (Noor \& Norlaila, 2014). Sementara itu peran guru di sekolah sangat dibutuhkan dalam tercapainya tujuan pembelajaran matematika serta proses belajar mengajar untuk membantu siswa mencapai hasil belajar yang optimal. Akan tetapi siswa merasa kesulitan dalam mempelajari dan memahami matematika terlihat dari siswa dalam mengaitkan antara konsep-konsep matematika (Fitri, Helma, \& Syarifuddin, 2014). Keabstrakan matematika menurut (Arifuddin \& Arrosyid, 2017) karena memang matematika berkaitan dengan simbol-simbol dan konsep-konsep, sehinga untuk mempelajarinya membutuhkan pemahaman dengan nalar yang tinggi. Oleh karena itu, untuk mengetahui kesulitan siswa dalam mempelajari materi-materi matematiika diperlukan sebuah strategi dan model pembelajaran yang sesuai dengan karakteristik materi matematika tersebut.

Berdasarkan hasil observasi yang dilakukan peneliti di MI Hidayatus Shibyan Kabupaten Cirebon, khususnya kelas IV Ali bin Abi Thalib ditemukan bahwa sebagian besar siswa kurang memahami konsep materi pecahan dan belum mampu memecahkan masalah dalam meyelesaikan soal-soal cerita yang berkaitan dengan pecahan. Hal ini karena materi pecahan merupakan salah satu materi yang dirasakan sulit oleh siswa pada mata pelajaran matematika. Sehingga mengakibatkan beberapa siswa menjadi enggan untuk berperan aktif pada saat proses kegiatan belajar mengajar berlangsung. Dan karena guru masih menggunakan cara konvensional dengan memberikan suatu aturan secara langsung untuk dihafal, diingat, dan model pembelajaran yang terapkan guru di kelas masih terpusat pada guru. Sehingga berdampak pada rendahnya tingkat pemahaman siswa terhadap materi yang disampaikan oleh guru. Hal ini, dapat dilihat dari nilai rata-rata hasil belajar ulangan harian pada materi pecahan yang masih rendah di bawah Kriteria Ketuntasan Minimal (KKM) yaitu sebesar 63, dimana nilai Kriteria Ketuntasan Minimal (KKM) pelajaran matematika yang ditetapkan di MI Hidayatus Shibyan sebesar 70.

Hal ini senada dengan penelitian sebelumnya yang dilakukan oleh (Remme, 2014), mengatakan bahwa salah satu materi matematika yang dirasa sulit dipelajari oleh siswa adalah materi pecahan. Kesulitan siswa dalam memahami konsep pecahan, membuat siswa merasa kusulitan dalam mengerjakan soal-soal yang berhubungan dengan materi pecahan. Dan banyak siswa juga merasakan bahwa matematika sebagai pelajaran yang membosankan dan menakutkan. Sementara itu, penelitian yang dilakukan oleh (Kadima, Mustami, \& Ismaimuza, 
2014), (Noor \& Norlaila, 2014), mengungkapkan bahwa hasil belajar matematika khususnya materi pecahan masih tergolong rendah, karena siswa masih merasa kesulitan dalam memahami konsep materi pecahan yang berdampak pada kesulitan siswa dalam mengerjakan soal yang berhubungan dengan materi pecahan.

Hal senada juga kemukakan oleh (Syafwan, 2013) dan (Noor \& Norlaila, 2014), dalam penelitiannya bahwa proses kegiatan belajar mengajar di kelas pada pembelajaran matematika umumnya masih dominan menggunakan metode konvensional yang dilakukan guru dengan ceramah yang dilanjutkan dengan latihan soal, sehingga terkadang sulit dimengerti oleh siswa dan dapat mempengaruhi rendahnya kemampuan siswa dalam memecahkan masalah. Oleh karena itu, dalam proses pembelajaran khususnya pembelajaran matematika siswa harus lebih aktif diajak untuk memecahkan masalah matematika yang sesuai dengan tingkat usia dan pengalaman yang nereka dapat dalam pembelajaran matematika.

Untuk mengatasi kesulitan siswa dalam memahami konsep dan memecahkan masalah dalam menyelesaikan soal-soal materi pecahan, perlu suatu cara atau strategi pembelajaran matematika yang menyenangkan, efektif dan efesien, sehingga dapat meningkatkan hasil belajar siswa. Salah satu cara atau strategi tersebut yaitu dengan penggunaan model pembelajaran, karena dengan model pembelajaran yang berbeda akan mempengaruhi siswa dalam menerima pelajaran, terutama pelajaran matematika pada materi pecahan. Saat ini banyak sekali modelmodel pembelajaran yang dapat digunakan dalam proses pembelajaran. Salah satunya dari model pembelajaran tersebut adalah model pembelajaran inkuiri.

Model pembelajaran inkuiri menurut (Asnidar, Khabibah, \& Sulaiman, 2018) adalah serangkaian kegiatan pembelajaran yang menekankan pada proses berpikir secara kritis dan analitis untuk mencari dan menemukan sendiri jawaban dari suatu masalah yang dipertanyakan. Proses berpikir itu sendiri biasanya dilakukan melalui tanya jawab antara guru dan siswa. Model pembelajaran inkuiri ini cocok untuk materi pecahan, karena materi ini adalah salah satu materi yang berhubungan dengan masalah dalam kehidupan sehari-hari, sehingga membutuhkan pemecahan masalah. Pada pembelajaran inkuiri ini guru mengarahkan siswa pada suatu masalah, sedangkan siswa berusaha memecahkan masalah tersebut dengan bimbingan guru. Selanjutnya siswa akan lebih percaya dalam penyelidikan dan membuat kesimpulan, sehingga proses penguasaan materi pelajaran dapat ditingkatkan (Sitorus, Hasruddin, \& Edi, 2017).

Menurut (Hosnan, 2014), ada beberapa hal yang menjadi ciri utama model pembelajaran inkuiri, yaitu seperti berikut: (1) model inkuiri menekankan kepada aktivitas secara maksimal untuk mencari dan menemukan, artinya model inkuiri menempatkan siswa sebagai subjek belajar. (2) seluruh aktivitas yang dilakukan siswa diarahkan untuk mencari dan menemukan jawaban sendiri dari sesuatu yang dipertanyakan, sehingga diharapkan dapat menumbuhkan 
sikap percaya diri (self belief). (3) tujuan dari penggunaan model pembelajaran inkuiri adalah mengembangkan kemampuan berpikir secara sistematis, logis, dan kritis, atau mengembangkan kemampuan intelektual sebagai bagian proses mental. Dengan demikian, dalam model pembelajaran inkuiri siswa tak hanya dituntut agar menguasai materi pelajaran, akan tetapi bagaimana mereka dapat menggunakan potensi yang dimilikinya.

Hal ini senada dengan penelitian sebelumnya oleh (Sitindaon, Bukit, \& Turnip, 2017), (Olibie \& Ezeoba, 2014), (Simatupang \& Tiarmaida, 2015), dan (Fatmaryanti, Sarwanto, \& Ashadi, 2015), mengatakan bahwa model pembelajaran inkuiri merupakan salah satu model pembelajaran yang dapat membantu siswa untuk memahami konsep dengan optimal dan dapat mengembangkan keterampilan pemecahan masalah melalui proses keterampilan berpikirnya. Inkuiri juga dapat meningkatkan hasil belajar siswa, karena penerapan model pembelajaran inkuiri dapat melatih siswa untuk berpikir secara kritis, logis dan sistematis serta lebih percaya diri mengemukakan apa yang ditemukan melalui proses inkuiri. Adapun tujuan dari penelitian ini adalah untuk mengetahui pengaruh model pembelajaran inkuiri terhadap kemampuan pemecahan masalah matematika siswa pada materi pecahan di kelas IV MI Hidayatus Shibyan Kabupaten Cirebon.

\section{METODE PENELITIAN}

Metode penelitian yang digunakan dalam penelitian ini adalah kuantitatif, karena data yang dikumpulkan peneliti berhubungan dengan angka-angka, sehingga cocok digunakan untuk membuktikan hipotesis yang telah ditetapkan. Penelitian ini dilakukan di MI Hidayatus Shibyan dengan populasi seluruh siswa kelas IV Ali bin Abi Thalib MI Hidayatus Shibyan yang berjumlah 21 siswa. Sementara itu, untuk menentukan jumlah sampel, peneliti mengacu dari ketentuan yang dikemukakan (Arikunto, 2006) yaitu: “untuk sekedar ancer-ancer maka apabila subyeknya kurang dari 100, lebih baik diambil semua, sehingga penelitiannya merupakan penelitian populasi totalitas. Selanjutnya jika subyeknya besar dapat diambil 10-15\% atau 20-25\%. Adapun untuk menetukan sampel, peneliti menggunakan teknik sampling jenuh, yaitu peneliti mengambil semua populasi dari kelas IV Ali bin Abi Thalib yang berjumlah 21 siswa untuk dijadikan sampel.

Teknik pengumpulan data pada penelitian ini menggunakan observasi, tes dan dokumentasi. Teknik observasi ini digunakan untuk mengumpulkan data tentang aktivitas guru dan siswa pada saat penerapan model pembelajaran inkuiri di kelas. pengambilan data melalui teknik observasi ini dilakukan dengan skala nilai dengan memberi tanda ceklist pada rentangan skor yang ada pada panduan observasi. Sementara itu, teknik tes digunakan untuk memperoleh data tentang kemampuan pemecahan masalah matematika siswa. Tes ini berbentuk uraian yang berjumlah 10 (sepuluh) soal yang berkaitan dengan materi pecahan dan mengacu pada kurikulum 
mata pelajaran kelas IV SD semester 2 (dua). Tes yang diberikan kepada siswa terdiri dari tes awal (pretest) dan tes akhir (posttest), hal ini dilakukan untuk mengetahui efektifitas pembelajaran dan peningkatan kemampuan pemecahan masalah. Setelah melakukan observasi dan tes, kemudian mengumpulkan data-data yang sudah diteliti dan foto hasil penelitian untuk dokumentasi.

Selanjutnya data hasil penelitian dianalisis menggunakan uji analisis data hasil observasi aktivitas guru dan siswa. Analisis data observasi digunakan untuk mendapatkan data variable $\mathrm{X}$ yaitu penggunaan model pembelajaran inkuiri. Dalam pengolahan data penelitian ini menggunakan rumus prosentase observasi menurut (Sugiyono, 2016) berikut ini:

$$
\mathrm{P}=\frac{\mathrm{F}}{\mathrm{N}} \times 100 \% \quad \text { atau } \quad \text { Rata-Rata }=\frac{\text { Jumlah nilai yang diperoleh }}{\text { Jumlah nilai keseluruhan }} \times 100 \%
$$

Sementara itu, data tes kemampuan pemecahan masalah matematika diuji menggunakan uji NGain dan Uji Regresi. Perhitungan uji N-Gain diperoleh dengan membandingkan antara skor pretest dan posttest dengan tujuan untuk mengetahui peningkatan kemampaun pemecahan masalah matematika materi pecahan antara sebelum dan sesudah pembelajaran dengan menggunakan model pembelajaran inkuiri. Adapun rumus Uji N-Gain menurut Hake dalam (Arifuddin, 2017) adalah N-Gain $=\frac{\text { Skor post test-skor pre test }}{\text { Skor maksimum-skor pre test }}$

Sedangkan uji regresi digunakan untuk melakukan prediksi seberapa tinggi nilai variabel dependen dan nilai variabel independen dimanipulasi (dirubah-rubah). Secara umum persamaan uji regresi dapat dirumuskan sebagai berikut: $Y=a+b X$

\section{HASIL DAN PEMBAHASAN}

\section{HASIL PENELITIAN}

\section{A. Penggunaan Model Pembelajaran Inkuiri pada Materi Pecahan di Kelas IV MI Hidayatus Shibyan}

Adapun hasil observasi aktivitas guru dalam proses pembelajaran di kelas adalah sebagaimana tabel 1 .

Tabel 1. Rekapitulasi Hasil Observasi Aktivitas Guru

\begin{tabular}{ccc}
\hline No & Uraian & Hasil \\
\hline 1 & Skor Maksimal & 72 \\
\hline 2 & Skor Akhir & 60 \\
\hline 3 & Prosentase Observasi Aktivitas Guru & $83 \%$ \\
\hline 4 & Kategori Tingkat Keberhasilan Guru & Baik \\
\hline
\end{tabular}

Berdasarkan tabel 1 terlihat bahwa rekapitulasi hasil observasi aktivitas guru dari 18 indikator diperoleh nilai prosentasenya adalah sebesar $83 \%$ dengan kategori penilaiannya 
adalah baik. Sementara itu, hasil observasi aktivitas siswa dalam proses pembelajaran di kelas dapat dilihat pada tabel 2 .

Tabel 2. Rekapitulasi hasil observasi aktivitas siswa

\begin{tabular}{|c|c|c|c|c|c|c|c|c|c|c|}
\hline \multirow{2}{*}{ No } & \multicolumn{2}{|c|}{ Kurang } & \multicolumn{2}{|c|}{ Cukup } & \multicolumn{2}{|c|}{ Baik } & \multicolumn{2}{|c|}{$\begin{array}{c}\text { Sangat } \\
\text { Baik }\end{array}$} & \multicolumn{2}{|c|}{ JUMLAH } \\
\hline & $\mathbf{F}$ & $\mathbf{P}(\%)$ & $\mathbf{F}$ & $\mathrm{P}(\%)$ & $\mathbf{F}$ & $P(\%)$ & $\mathbf{F}$ & $\mathrm{P}(\%)$ & $\mathbf{F}$ & $\mathbf{P}(\%)$ \\
\hline 1 & 0 & $0 \%$ & 0 & $0 \%$ & 16 & $76 \%$ & 5 & $24 \%$ & 21 & $100 \%$ \\
\hline 2 & 0 & $0 \%$ & 0 & $0 \%$ & 15 & $71 \%$ & 6 & $29 \%$ & 21 & $100 \%$ \\
\hline 3 & 0 & $0 \%$ & 14 & $67 \%$ & 7 & $33 \%$ & 0 & $0 \%$ & 21 & $100 \%$ \\
\hline 4 & 0 & $0 \%$ & 5 & $24 \%$ & 16 & $76 \%$ & 0 & $0 \%$ & 21 & $100 \%$ \\
\hline 5 & 0 & $0 \%$ & 0 & $0 \%$ & 11 & $52 \%$ & 10 & $48 \%$ & 21 & $100 \%$ \\
\hline 6 & 0 & $0 \%$ & 0 & $0 \%$ & 9 & $43 \%$ & 12 & $57 \%$ & 21 & $100 \%$ \\
\hline 7 & 0 & $0 \%$ & 0 & $0 \%$ & 10 & $48 \%$ & 11 & $52 \%$ & 21 & $100 \%$ \\
\hline 8 & 0 & $0 \%$ & 0 & $0 \%$ & 21 & $100 \%$ & 0 & $0 \%$ & 21 & $100 \%$ \\
\hline $\begin{array}{c}\text { Rata- } \\
\text { rata }\end{array}$ & 0 & $0 \%$ & 2.375 & $11 \%$ & 13.13 & $63 \%$ & 5.5 & $26 \%$ & 21 & $100 \%$ \\
\hline
\end{tabular}

Berdasarkan tabel 2 hasil observasi aktivitas siswa diketahui bahwa 26\% rata-rata aktivitas siswa menunjukkan aktivitas sangat baik dan 63\% rata-rata aktivitas siswa menunjukkan baik. Namun demikian, masih terdapat $11 \%$ rata-rata aktivitas siswa yang menunjukkan cukup. Untuk mempermudah dalam memahami data hasil observasi aktivitas siswa dapat disajikan ke dalam diagaram berikut:

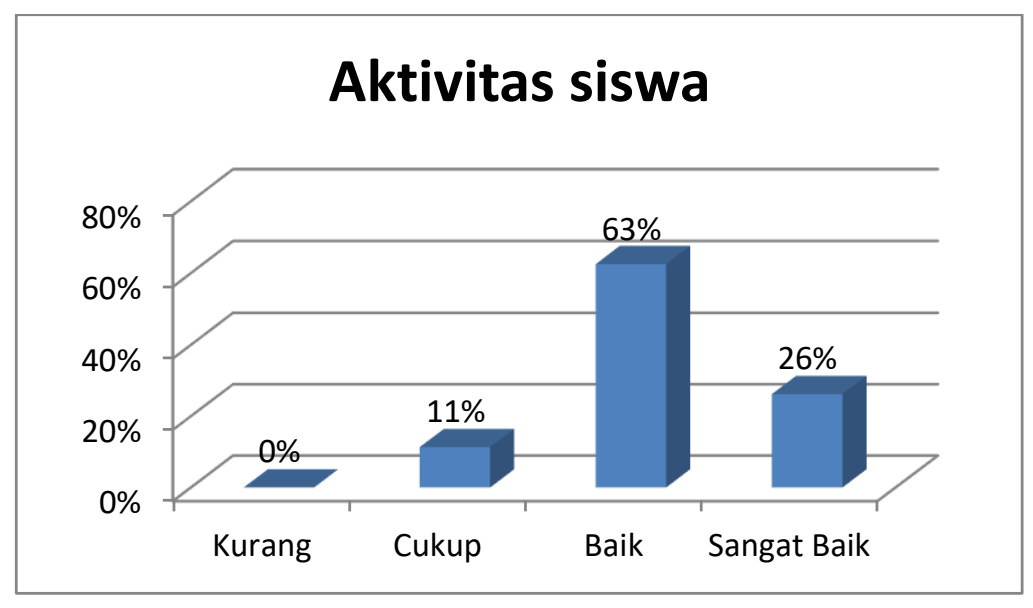

Gambar 1. Diagram hasil observasi aktivitas siswa

Adapun deskripsi hasil analisis data observasi aktivitas siswa adalah sebagai berikut:

a. Siswa menyimak penjelasan guru mengenai tujuan pembelajaran dengan baik.

b. Siswa memperhatikan guru pada saat menjelaskan materi pecahan dengan baik.

c. Siswa dapat memahami pertanyaan yang diajukan oleh guru sampai dengan cara penyelesaian pertanyaannya, sudah terlihat baik. Dapat dilihat dari siswa sudah mampu berpikir kritis dalam menemukan jawaban dari pertanyaan yang diberikan.

d. Siswa mampu menyimpulkan materi yang sudah diajarkan oleh guru. 


\section{B. Kemampuan Siswa dalam Pemecahan Masalah Materi Pecahan di Kelas IV MI Hidayatus Shibyan}

Untuk mengukur kemampuan pemecahan masalah matematika siswa pada materi pecahan, peneliti melakukan tes tulis. Namun sebelum pelaksanaan proses pembelajaran, peneliti terlebih dahulu melakukan tes awal (pre-test). Selanjutnya dilaksanakan proses pembelajaran dengan menggunakan model pembelajaran inkuiri. Dan setelah proses pembelajaran dan seluruh materi tersampaikan, barulah peneliti melakukan tes akhir (posttest).

Adapun hasil prestest tes kemampuan pemecahan masalah matematika siswa dapat disajikan sebagaimana tabel 3 berikut:

Tabel 3. Hasil Prestest

\begin{tabular}{crr}
\multicolumn{3}{c}{ Statistics } \\
\hline \multicolumn{3}{c}{ Pretest } \\
\hline \multirow{2}{*}{$\mathrm{N}$} & Valid & 21 \\
\cline { 2 - 3 } & Missing & 0 \\
\hline Mean & 42.8571 \\
\hline Median & 50.0000 \\
\hline Mode & 60.00 \\
\hline Minimum & 10.00 \\
\hline Maximum & 60.00 \\
\hline Sum & 900.00 \\
\hline
\end{tabular}

Berdasakan tabel 3 diketahui bahwa dari 21 siswa yang mengikuti tes diperoleh mean atau nilai rata-rata pretest sebesar 42,86 , nilai minimum sebesar 10.00 dan nilai maximum sebesar 60.00. Ini menunjukkan bahwa sebagaian besar hasil tes kemampuan pemecahan masalah matematika siswa pada materi pecahan masih rendah, yakni 42,86.

Sementara itu, hasil posttest tes kemampuan pemecahan masalah matematika siswa pada materi pecahan dapat disajikan pada tabel 4 berikut:

Tabel 4. Hasil Postest

\begin{tabular}{crr}
\hline \multicolumn{3}{c}{ Statistics } \\
\hline \multicolumn{3}{c}{ Posttest } \\
\hline \multirow{2}{*}{$\mathrm{N}$} & Valid & 21 \\
\cline { 2 - 3 } & Missing & 0 \\
\hline Mean & 86.1905 \\
\hline Median & 90.0000 \\
\hline Mode & 80.00 \\
\hline Minimum & 70.00 \\
\hline Maximum & 100.00 \\
\hline Sum & 1810.00 \\
\hline
\end{tabular}

Pada tabel 4 terlihat bahwa dari 21 siswa yang mengikuti tes diperoleh mean atau nilai rata-rata posttest sebesar 86,19 , nilai minimum sebesar 70.00 dan nilai maximum 
sebesar 100.00. Ini menunjukkan bahwa sebagaian besar hasil posttest kemampuan pemecahan masalah matematika siswa pada materi pecahan tinggi, yakni 86,19.

Berdasarkan hasil pretest dan posttest tes kemampuan pemecahan masalah matematika siswa pada materi pecahan menunjukkan bahwa terjadi peningkatan antara hasil prestest dengan hasil posttest. Untuk mengetahui seberapa besar peningkatannya kita dapat menggunakan uji N-Gain. Adapun hasil perhitungan uji N-Gain adalah sebagimana tabel 5 berikut:

Tabel 5. Hasil Uji N-Gain

\section{Kriteria Indeks Gain Tiap Siswa}

\begin{tabular}{cccccccc}
\hline \multicolumn{2}{c}{ Rendah } & \multicolumn{2}{c}{ Sedang } & \multicolumn{2}{c}{ Tinggi } & Hasil Rataan & $\begin{array}{c}\text { Kriteria } \\
\text { Indeks Gain }\end{array}$ \\
\cline { 1 - 5 } F & Persen & F & Persen & F & Persen & Gain \\
\hline 2 & $10 \%$ & 11 & $52 \%$ & 8 & $38 \%$ & 0.78 & Tinggi \\
\hline
\end{tabular}

Berdasarkan tabel 5 menunjukkan bahwa yang mengalami peningkatan dengan kategori tinggi sebanyak 8 siswa (38\%), peningkatan dengan kategori sedang sebanyak 11 siswa (52\%) dan yang mengalami peningkatan dengan kategori rendah sebanyak 2 siswa $(10 \%)$. Adapun rata-rata peningkatan indeks gain ternormalisasi dari pretes ke postes adalah sebesar 0,78 dengan kategori tinggi.

\section{Pengaruh Model Pembelajaran Inkuiri Terhadap Kemampuan Pemecahan Masalah Matematika pada Materi Pecahan di Kelas IV MI Hidayatus Shibyan}

Untuk mengetahui ada tidaknya pengaruh penggunaan model pembelajaran inkuiri terhadap kemampuan pemecahan masalah matematika siswa dapat dilakukan dengan uji regresi, yang meliputi uji determinasi dan uji koefesien regrsi.

a. R Square (Uji Determinasi)

Adapun hasil uji determinasinya adalah sebagaimana tabel 6 berikut.

Tabel 6. Uji Determinasi

\begin{tabular}{ccccr}
\hline \multicolumn{5}{c}{ Model Summary } \\
\hline Model & R & R Square & $\begin{array}{c}\text { Adjusted R } \\
\text { Square }\end{array}$ & $\begin{array}{c}\text { Std. Error of } \\
\text { the Estimate }\end{array}$ \\
\hline 1 & $.691^{\mathrm{a}}$ & $.47,8 \%$ & .450 & .11155 \\
\multicolumn{5}{c}{478} \\
\hline \multicolumn{4}{l}{ a. Predictors: (Constant), Model Pembelajaran Inkuiri }
\end{tabular}

Berdasarkan tabel 6 diperoleh bahwa hasil R Square sebesar 0,478 (kuadrat dari koefisien korelasi 0,691). R Square disebut koefisien determinan yang dalam hal ini sebesar 47,8\%. Dari nilai tersebut dapat diartikan bahwa penggunaan model pembelajaran inkuiri berpengaruh terhadap kemampuan pemecahan masalah pada materi 
pecahan di kelas IV MI Hidayatus Shibyan. Besarnya pengaruh penggunaan model pembelajaran inkuiri sebesar $47,8 \%$, sedangkan sisanya $52,2 \%$ dipengaruhi oleh faktor lain.

b. Uji Koefisien Regresi

Adapun hasil uji koefisien regresinya adalah sebagaimana tabel 7 berikut.

Tabel 7. Uji Koefisien Regresi

\begin{tabular}{|c|c|c|c|c|c|c|}
\hline \multicolumn{7}{|c|}{ Coefficients $^{\mathrm{a}}$} \\
\hline \multirow{2}{*}{\multicolumn{2}{|c|}{ Model }} & \multicolumn{2}{|c|}{$\begin{array}{l}\text { Unstandardized } \\
\text { Coefficients }\end{array}$} & \multirow{2}{*}{$\begin{array}{c}\begin{array}{c}\text { Standardized } \\
\text { Coefficients }\end{array} \\
\text { Beta }\end{array}$} & \multirow[t]{2}{*}{$\mathrm{T}$} & \multirow[t]{2}{*}{ Sig. } \\
\hline & & $\mathrm{B}$ & Std. Error & & & \\
\hline & (Constant) & -.718 & .360 & & -1.995 & .061 \\
\hline 1 & $\begin{array}{l}\text { Model Pembelajaran } \\
\text { Inkuiri }\end{array}$ & .059 & .014 & .691 & 4.168 & .001 \\
\hline
\end{tabular}

a. Dependent Variable: Kemampuan Pemecahan Masalah

$\mathbf{Y}=\mathbf{a}+\mathbf{b X}$

Y adalah variabel dependent, dalam hal ini adalah kemampuan pemecahan masalah, dan $\mathrm{X}$ adalah variabel independen, dalam hal ini adalah model pembelajaran inkuiri. Sedangkan a dan $b$ adalah nilai konstanta yang dicari.

Berdasarkan hasil regresi diketahui bahwa nilai constant-nya adalah -0,718 dan nilai kemampuan pemecahan masalah adalah 0,059. Dari keterangan tersebut kita dapat memperoleh persamaan regresi sebagai berikut:

$$
\mathbf{Y}=-0,718+0,059 \mathbf{X}
$$

Nilai konstanta dari koefficien regresi sebesar $-0,718$, hal ini menyatakan bahwa jika tidak ada kenaikan nilai atau skor dari variabel Model Pembelajaran Inkuiri, maka variabel Kemampuan Pemecahan Masalah adalah -0,718. Koefficien regresi sebesar 0,059 menyatakan bahwa setiap terjadi penambahan skor variabel model pembelajaran inkuiri akan dapat menambah kenaikan variabel kemampuan pemecahan masalah.

Setelah megetahui besarnya koefisien regresi, maka perlu dilakukan pengujian hipotesis dengan menggunakan uji t untuk megetahui apakah terdapat pengaruh atau tidak. Uji hipotesis dapat dinyatakan dengan membandingkan nilai signifikan yaitu :

Jika nilai signifikan $>0,05$ dan $\mathrm{t}_{\text {hitung }}<\mathrm{t}_{\text {tabel }}$, maka $\mathrm{H}_{0}$ diterima

Jika nilai signifikan $<0,05$ dan $t_{\text {hitung }}>\mathrm{t}_{\text {tabel }}$, maka $\mathrm{H}_{0}$ ditolak

Jika $\mathrm{t}_{\text {tabel }}$ dicari dengan $\alpha=0,05$ dan (df) $\mathrm{n}-\mathrm{k}-1$ atau $20-2=18$, jadi $\mathrm{t}_{\text {tabel }}=1.73406$

Berdasarkan hasil uji regresi di atas nilai signifikansinya sebesar 0,01. Karena nilai signifikansinya lebih kecil dari 0,05 dan $\mathrm{t}$ hitung (4.168) lebih besar dari $\mathrm{t}$ tabel (1.73406) maka Ho ditolak, artinya bahwa terdapat pengaruh signifikan penggunaan 
model pembelajaran inkuiri terhadap kemampuan pemecahan masalah pada materi pecahan di kelas IV MI Hidayatus Shibyan Kabupaten Cirebon.

\section{PEMBAHASAN}

Berdasarkan data yang diperoleh dari hasil observasi aktivitas guru dan siswa, diketahui bahwa skor maksimal untuk lembar observasi aktivitas guru adalah sebesar 72, sementara itu, skor hasil observasi aktivitas guru adalah sebesar 60. Oleh karena itu, prosentase dari observasi aktvitas guru adalah $\frac{60}{72} \times 100 \%=83 \%$

Skor tersebut dapat dikategorikan baik karena berada di interval 76 - 100\%. Sedangkan hasil observasi aktivitas siswa yang diperoleh dari rekapitulasi aktivitas siswa adalah terdapat $26 \%$ rata-rata aktivitas siswa menunjukkan aktivitas sangat baik dan 63\% rata-rata aktivitas siswa menunjukkan baik. Namun demikian, terdapat $11 \%$ rata-rata aktivitas siswa yang menunjukkan cukup. Maka dapat disimpulkan bahwa hasil observasi aktivitas guru dan siswa rata-rata berada di interval 76 - $100 \%$ yang dapat dikategorikan baik. Hal ini dikarenakan penggunaan model pembelajaran inkuiri dalam proses pembelajaran memiliki banyak kelebihan. Diantara kelebihan-kelebihan model pembelajaran inkuiri menurut (Simbolon \& Sahyar, 2015), diantaranya adalah sebagai berikut: (a) model pembelajaran inkuiri merupakan model pembelajaran yang menekankan kepada pengembangan aspek kognitif, afektif, dan psikomotor secara seimbang, sehingga pembelajaran melalui model ini dianggap lebih bermakna. (b) model pembelajaran inkuiri memberikan ruang kepada siswa untuk belajar sesuai dengan gaya belajar mereka. (c) model pembelajaran inkuiri merupakan model yang dianggap sesuai dengan perkembangan psikologi belajar modern yang menganggap belajar adalah proses perubahan tingkah laku berkat adanya pengalaman. (d) keutungan lain model pembelajaran ini dapat melayani kebutuhan siswa yang memiliki kemampuan di atas rata-rata. Artinya, siswa yang memiliki kemampuan belajar bagus tidak akan terhambat oleh siswa yang lemah dalam belajar.

Sementara itu, dari hasil prestest dan posttest kemampuan siswa dalam pemecahan masalah matematika diketahui bahwa hasil tes kemampuan pemecahan masalah matematika siswa pada materi pecahan masih rendah, yakni 42,86. Ini berarti bahwa hasil prestest kemampuan pemecahan masalah matematika siswa masih di bawah nilai KKM yang ditentukan untuk mata pelajaran matematika yaitu sebesar 70. Sedangkan hasil posttest kemampuan pemecahan masalah matematika siswa pada materi pecahan termasuk tinggi, yakni 86,19. Dengan demikian, maka dapat kita simpulkan bahwa terjadi peningkatan antara hasil prestest dengan hasil posttest. Adapun rata-rata peningkatan indeks gain ternormalisasi dari pretes ke postes adalah sebesar 0,78 dengan kategori tinggi. 
Selanjutnya, Berdasarkan hasil uji koefisien regresi menunjukan bahwa nilai signifikansinya sebesar 0,01. Karena nilai signifikansinya lebih kecil dari 0,05 dan $\mathrm{t}_{\text {hitung }}$ (4.168) lebih besar dari $\mathrm{t}$ tabel (1.73406) maka Ho ditolak, artinya bahwa terdapat pengaruh signifikan antara model pembelajaran inkuiri terhadap kemampuan pemecahan masalah pada materi pecahan di kelas IV MI Hidayatus Shibyan. Berdasarkan nilai $r=0,691$ berada diantara 0,600 0,799 yang berarti bahwa penggunaan model pembelajaran inkuiri berpengaruh terhadap kemampuan pemecahan masalah pada materi pecahan di kelas IV MI Hidayatus Shibyan. Besarnya pengaruh penggunaan model pembelajaran inkuiri sebesar 47,8 \%, sedangkan sisanya $52,2 \%$ dipengaruhi oleh faktor lain. Sementara persamaan regresinya yaitu $\mathbf{Y}=-0,718+$ 0,059X. Ini berarti, jika tanpa penggunaan model pembelajaran inkuiri maka hasil kemampuan pemecahan masalah adalah -0,718 dan koefesien regresi sebesar 0,059. Dengan demikian, maka dapat disimpulkan bahwa terdapat pengaruh signifikan penggunaan model pembelajaran inkuiri terhadap kemampuan pemecahan masalah pada materi pecahan di kelas IV MI Hidayatus Shibyan Kabupaten Cirebon.

Hasil penelitian ini senada dengan penelitian yang dilakukan oleh (Nazaruddin, 2011), (Remme, 2014), (Prahani, Limatahu, w., Yuanita, \& Nur, 2016), (Lazonder \& Harmsen, 2016), dan (Bayram, Oskay, Erdem, Ozgur, \& Sen, 2013) yang mengungkapkan bahwa penggunaan model pembelajaran inkuiri dalam proses pembelajaran sangat berpengaruh terhadap motivasi, aktivitas dan hasil belajar siswa.

\section{KESIMPULAN}

Berdasarkan paparan data dan temuan peneltian di lapangan dapat disimpulkan sebagai berikut:

1. Berdasarkan data yang diperoleh dari hasil observasi aktivitas guru dan aktivitas siswa menunjukkan bahwa aktivitas guru dalam proses pembelajaran prosentasenya adalah sebesar $83 \%$ dengan kategori penilaiannya adalah baik. Sementara itu, hasil observasi aktivitas siswa diketahui bahwa $26 \%$ rata-rata aktivitas siswa menunjukkan aktivitas sangat baik dan $63 \%$ rata-rata aktivitas siswa menunjukkan baik

2. Berdasarkan hasil prestest dan posttest kemampuan siswa dalam pemecahan masalah matematika, diketahui bahwa hasil prestest kemampuan pemecahan masalah matematika siswa pada materi pecahan masih rendah, yakni 42,86. Ini berarti bahwa hasil prestest kemampuan pemecahan masalah matematika siswa masih di bawah nilai KKM yang ditentukan untuk mata pelajaran matematika yaitu sebesar 70. Sementara itu, hasil posttest kemampuan pemecahan masalah matematika siswa pada materi pecahan termasuk tinggi, yakni 86,19 . Berdasarkan hasil pretest dan posttest tes kemampuan pemecahan masalah 
matematika siswa pada materi pecahan menunjukkan bahwa terjadi peningkatan antara hasil prestest dengan hasil posttest. Adapun rata-rata peningkatan indeks gain ternormalisasi dari pretes ke postes adalah sebesar 0,78 dengan kategori tinggi.

3. Dari hasil uji koefisien regresi menunjukan bahwa nilai signifikansinya sebesar 0,01. Karena nilai signifikansinya lebih kecil dari 0,05 dan $t$ hitung (4.168) lebih besar dari $t$ tabel (1.73406) maka Ho ditolak, artinya bahwa terdapat pengaruh signifikan antara model pembelajaran inkuiri terhadap kemampuan pemecahan masalah pada materi pecahan di kelas IV MI Hidayatus Shibyan.

\section{DAFTAR PUSTAKA}

Anam, K. (2016). Pembelajaran Berbasis Inkuiri Metode dan Aplikasi. Yogyakarta: Pustaka Pelajar.

Arifuddin, A. (2017). Efektivitas Model Quantum Teaching dengan Pendekatan Realistik untuk Meningkatkan Hasil Belajar Peserta Didik pada Materi Bangun Ruang. JMIE: Journal of Madrasah Ibtidaiyah Education, 1(2), 217-226.

Arifuddin, A., \& Arrosyid, S. R. (2017). Pengaruh Metode Demontrasi dengan Alat Peraga Jembatan Garis Bilangan Terhadap Hasil Belajar Matematika Materi Bilangan Bulat. Al Ibtida: Jurnal Pendidikan Guru MI, 4(2), 165-178.

Arikunto, S. (2006). Prosedur Penelitian; Suatu Pendekatan Praktik. Jakarta: RIneka Cipta.

Asnidar, Khabibah, S., \& Sulaiman, R. (2018). The Effectiveness of Guided Inquiri Learning for Comparison Topics. Jurnal of Physics: Conference Series, 1-6.

Bayram, Z., Oskay, O. O., Erdem, E., Ozgur, D. S., \& Sen, S. (2013). Effect of Inquiry Based Learning Method on Students' Motivation. 4th International Conference on New Horizons in Education (hal. 988-996). Ankara: Procedia Sosial and Behavioral Sciences.

Fatmaryanti, S. D., Sarwanto, \& Ashadi. (2015). Implementation of Guided Inquiry in Physics Learning at Purworejo's Senior High School. International Conference on Mathematics, Science, and Education, 12-15.

Fitri, R., Helma, \& Syarifuddin, H. (2014). Penerapan strategi The Firing pada Pembelajaran Matematika Siswa Kelas XI IPS Negeri 1 Batiputih. Jurnal Pendidikan Matematika, 3(1), 18-22.

Hosnan, M. (2014). Pendekatan Saintifik dan Kontekstual dalam Pembelajaran Abad 21. Jakarta: Ghalia Indonesia.

Kadima, Mustami, \& Ismaimuza, D. (2014). Meningkatkan Hasil Belajar Siswa pada Materi Pecahan Melalui Model Pembelajaran Kooperatif Tipe STAD di Kelas IV SDN Balayon Kecamatan Liang. Jurnal Kreatif Tadulako, 2(2), 205-210.

Lazonder, A. W., \& Harmsen, R. (2016). Meta-Analysis of Inquiry Based Learning: Effect of Guidance. Review of Educational Research, 20(10), 1-38.

Nazaruddin. (2011). Keefektifan Model Inkuiri dengan Pemanfaatan Alat Peraga Dibandingkan dengan CD Interaktif Terhadap Kemampuan Pemecahan Masalah. Jurnal Matemaika dan Pendidikan Matematika, 2(2), 1-12. 
Noor, A. J., \& Norlaila. (2014). Kemampuan Pemecahan Masalah Matematika Siswa dalam Pembelajaran Matematika Menggunakan Model Cooperative Script. Jurnal Pendidikan Matematika, 2(3), 250-259.

Olibie, E. I., \& Ezeoba, K. O. (2014). Ability and Location Differences in the Effect of GuidedInquiry on Negerian Students' Achievement in Social Studies Curriculum. International Journal of Educational Science, 3(4), 335-344.

Prahani, B. K., Limatahu, I., w., S. w., Yuanita, L., \& Nur, M. (2016). Effectiveness of Physic Learning Material Trough Guided Inquiry Model to Improve Students Problem Solving Skill Based on Multiplle Representation. International Journal of Education and Research, 4(12), 231-242.

Remme, B. V. (2014). Pengaruh Model Pembelajaran Inkuiri Terhadap Prestasi Belajar Matematika Siswa Kelas X SMA Katolik Disamakan Makale. Jurnal KIP, 3(2), 583-587.

Simatupang, S., \& Tiarmaida. (2015). Pengaruh Model Pembelajaran Inkuiri Terhadap Hasil Belajar Siswa pada Materi Pokok Listrik Dinamis di Kelas X Semester II SMA Negeri 8 Medan T.P. 2013/2014. Jurnal Ikatan Alumni Fisika Universitas Negeri Medan, 1(1), 3441.

Sitindaon, S. F., Bukit, N., \& Turnip, B. M. (2017). The Effect of Guided Inquiry Learning Using PhET Media on Students' Problem Solving Skill and Critical Thinking. Jurnal of Education and Practice, 8(21), 129-134.

Sitorus, H. H., Hasruddin, \& Edi, S. (2017). The Influence of Inquiry Learning Model on Student's Scientific Attitudes in Ecosystem Topik at MTs Darul Hikmah Sei Ali, (Islamic Junior High School) Asahan. Internaional Journal of Humanities Social Sciences and Education (IJHSSE), 4(11), 170-175.

Sugiyono. (2016). Metode Penelitian Pendidikan Pendekatan Kuantitatif, Kualitatif, dan R\&D. Bandung: Alfabeta.

Syafwan. (2013). Meningkatkan Hasil Belajar Matematika Siswa Melalui Strategi Pembelajaran Kooperatif Tipe Tutor Sebaya untuk Siswa Kelas VII-A SMP Negeri 2 Poso Pesisir. Jurnal Kreatif Tadulako, 4(4), 227-238.

Udin, T., \& Hikmah, N. (2014). Pengaruh Penerapan Metode Problem Solving Terhadap Hasil Belajar Siswa Mata Pelajaran Matematika Pokok Bahasan Pecahan pada Siswa Kelas IV SD Negeri Legok 1 Kabupaten Indramayu. Al Ibtida: Jurnal Pendidikan Guru MI, 1(1), $1-22$. 